\title{
The Influence of Current Ratio, Total Debt to Total Assets, Total Assets Turn Over, and Return on Assets on Earnings Persistence in Automotive Companies
}

\author{
Adibah Yahya \\ Universitas Pelita Bangsa \\ Saepul Hidayat \\ Universitas Pelita Bangsa
}

\begin{abstract}
The purpose of this study is to determine the effect of the variable Current Ratio, Total Debt to Total Assets, Total Assets Turnover, Return on Assets, on earnings persistence. This study used secondary data, namely the annual financial statements of automotive companies listed on the Indonesia Stock Exchange from 2014-2018. The sample selection used a purposive sampling method. The data source is the financial ratios of automotive companies listed on the IDX. Methods of data analysis used the classic assumption test, multiple linear regression, T-test, F-test, and the coefficient of determination. The results showed that partial earnings persistence expressed in financial ratios consisting of the Return on Assets (ROA) significantly affect earnings persistence, while the Current Ratio (CR), Total Debt To Total Asset (TDTA) and Total Asset variables and Total Assets Turnover (TATO) has no significant effect on earnings persistence. Results of the simultaneous test, financial ratios consisting of CR, TDTA, TATO, and ROA had no significant effect on earnings persistence. R Square value of 0.076 can be interpreted that CR, TDTA, TATO, and ROA of $7.6 \%$ while the remaining $82.4 \%$ is influenced by other variables not examined.
\end{abstract}

Keywords: Current Ratio; Total Debt To Total Assets; Total Assets Turnover; Return On Assets; Earnings Persistence

\section{Introduction}

Indonesia is currently improving; almost all sectors are experiencing significant changes amid the uncertainty of the world economy. It is evidenced by statistical data that shows that Indonesia's economic growth in the last five years, which was in the range of $5.01 \%$ in 2014 and continued to rise and reached its peak in 2018 with a rate of $5.17 \%$ (BPS, 2019). It is indeed inseparable from the success of various parties, one of which is that the sector that received priority attention was the construction of a very massive road infrastructure that was carried out throughout Indonesia. In the last 4, recorded the government has built 3,432 KM of

new roads through the Ministry of PUPR (Detik, 2018). Of course, the impact of the construction of this road infrastructure has an impact on the increasing stretch of the surrounding economy and manufacturing in the automotive sector is the most favorable party with this condition.

During the year 2018, Indonesia's fourwheeled vehicle production compiled by the Indonesian Automotive Industries Association (GAIKINDO) reached 1.34 Million Units, or an increase of $10.4 \%$ from the previous year (Gaikindo, 2019). While the data obtained from the Indonesian Motorcycle Industry Association (AISI) stated the total motorcycle market in 
2018 then reached $6,383,111$ units. This figure has increased by 8.4 percent compared to 2017 sales, with the number of motorcycles sold $5,886,103$ units (Tempo, 2019). The data shows that the automotive industry sector in the country is experiencing a significant increase so that it is expected to have an impact on corporate profits. However, rapid production and sales are indeed only one of the factors that support the company's profit growth. Research shows that a factor that significantly affects earnings income is the company's ability to carry out operational activities in a stable manner (Pramesti et al., 2016). The efficiency of costs by the company is a significant factor in the maximum profitability of the company (Anggraeni, 2015). However, Mahaputra (2012) improve that it turns out that the company's financial performance is a determining factor in achieving the company's profit target. As is known, profit is the main target in a business, whether small, medium, or large scale. Especially in large industrial sectors, the concept of accounting reports is essential to investors in decision making. Especially when going to invest, so often the company's financial history from year to year is a particular concern before making an investment transaction so that investors can analyze future profits or, in other words, the persistence of the company's profits.

From the phenomena that occur, then to find out the cause of persistent company profit testing is needed on the factors that affect changes in company earnings, one thing that can be done is to analyze the company's financial statements through the financial ratio analysis method. Ratio analysis is needed to find out the company's financial history, and the results can be used to predict the company's financial situation going forward so that the company is expected to survive and earn profits according to the expectations and targets that have been set. Ratios that can affect earnings changes are The Current Ratio, Return On Assets, Total Debt To Total Assets, and sales growth (Puspitawati, 2017). Meanwhile, according to research by Sholihah (2012), Ratios that can affect changes in earnings are Liquidity, Solvency, Profitability, and Activity.

Current Ratio is a ratio to measure a company's ability to pay short-term obligations or debt that is due immediately when billed as a whole. According to Susilawati \& Iskandar, (2017), Anggraeni (2015), Indriyani (2015) in their research stated that the Current Ratio had a significant effect on changes in company earnings, while according to Gunawan \& Wahyuni (2014), Sitanggang \& Vivandi (2015) showed that Current Ratio did not significantly influence earnings changes. Based on these results, there are inconsistencies, so researchers want to reexamine the effect of the Current Ratio on earnings persistence.

Total Debt To Total Assets is a ratio to determine the participation of debt in assets (Puspitawati, 2017). The high percentage will be directly proportional to the participation of debt in company assets. The results of research by Yulia (2013), Sholihah (2012), and Yusra (2016) show that TDTA has a significant effect on company profits. However, different results from Gunawan \& Wahyuni (2014) and Sitanggang \& Vivandi (2015) stated that TDTA had no significant effect on company profits. Based on the results of the study there were inconsistencies, so researchers wanted to reexamine the effect of Total Debt To Total Assets on Profit persistence

Total Assets Turnover is a ratio to determine the use of assets in generating sales (Eni, 2010). Research results by Hamidu (2013), Gunawan \& Wahyuni (2014) show that TATO significantly influences company profits. However, different results from Indriyani (2015) and Anggraeni (2015) stated that TATO did not significantly influence company profits. Based on the results of the study there were inconsistencies, so researchers wanted to reexamine the effect of Total Asset Turnover on Profit persistence

Return on Assets is a ratio that shows a company's ability to make a profit from ownership of assets (Puspitawati, 2017). The results of research by Budiasih (2009), Naimah \& Utama (2006), and Indriyani (2015) show that ROA significantly influences company profits. However, different results from Ariyanti (2010) and Sofiah et al. (2017) stated that ROA did not significantly influence company profits. Based on the results of the study, there were inconsistencies, so researchers wanted to reexamine the effect of Return On Assets on Earning persistence. 


\section{Theoretical Framework and Hypothesis Development}

Profit is the main target of a company in conducting business operations (Kasmir, 2015). Management will always make a profit plan in the form of targets every year. This target determination is done to be used as motivation as a whole from every element of the company. The profit will be utilized by all elements, both owners and management. For example, to increase the income of the company owner or for the welfare of employees who work at the company. Profit will also be allocated to restructure the company's capital so that the company can expand its business. However, if profit is not obtained or in other words is a loss, it will impact both in the near or long term. In the short term, for example, the company will have difficulty paying down debt or management loses the opportunity to get a bonus, but if in the long run, there will be a reduction in employees and even bankruptcy.

Earnings persistence is the company's performance which is presented in the form of earnings. Persistent profit is a profit that is sustainable for a long time (Fanani, 2010). The higher profits earned by the operating assets indicate more persistent earnings and more able to maintain the current earnings (Safaeian Rezi \& Sadeghi, 2009). The earning persistence mediated the effect of debt level toward stock return significantly (Hanifah \& Khafid, 2016).

\section{The Effect of Current Ratio on earnings persistence}

The current ratio divides total current assets with current debt, meaning that the value of assets is the number of times current debt (Munawir, 2014), (Hanafi, 2016) and (Kasmir, 2015). This ratio states the collection of accounts in current assets that can be held in less than one year against the number of accounts in current debt. Overall this ratio is a form of measuring the level of corporate security. Current assets are ownership that can be used as a means of paying off debt shortly, for example, cash in banks, securities, and receivables. While current debt is a short-term corporate obligation in less than one year. For example, trade debt, bank debt, salary debt, tax debt, and others. From the calculation results, if the ratio is low, then the company is in a condition of lack of funds to pay debts, and vice versa. However, when the high ratio does not necessarily mean that the company is in good condition, it could be because the cash is not rotated optimally. The Current Ratio had a significant effect on changes in company earnings (Susilawati \& Iskandar, 2017), (Indriyani, 2015), and (Anggraeni, 2015) while according to (Gunawan \& Wahyuni, 2014) and (Sitanggang \& Vivandi, 2015) showed that Current Ratio did not significantly influence earnings changes. Based on these results, there are inconsistencies, so researchers want to reexamine the effect of the Current Ratio on earnings persistence. Therefore, the hypothesis is proposed as follows:

\section{Hypothesis 1: Current Ratio has a significant effect on earnings persistence}

\section{The Effect of Total Debt To Total Asset on Earnings persistence}

Total Debt To Total Asset ratio is obtained by dividing total debt by total assets (Munawir, 2014). This ratio is a reference for companies to get new loans because they contain the value of security guarantees for creditors in the long run. TDTA ratio is used to measure the amount of long-term debt in the company's capital structure (Hanafi, 2016). Meanwhile, according to Kasmir (2015), this ratio is part of solvency, namely by dividing total debt by total assets. In other words, how much debt the company is building an asset account. From the measurement results, if the results are high, it means that there will be more funding with debt. The industry average is $35 \%$.

Total Debt To Total Assets is a ratio to determine the participation of debt in assets (Puspitawati, 2017). The high percentage will be directly proportional to the participation of debt in company assets. The results of research from Yulia (2013), Sholihah (2012), and Yusra (2016) show that TDTA has a significant effect on company profits. However, different results from Gunawan \& Wahyuni (2014) and Sitanggang \& Vivandi (2015) stated that TDTA had no significant effect on company profits. 
Based on the results of the study, there were inconsistencies, so researchers wanted to reexamine the effect of Total Debt To Total Assets on Profit persistence. Therefore, the hypothesis is proposed as follows:

Hypothesis 2: Total Debt To Total Assets has a significant effect on earning persistence

\section{The Effect of Total Asset Turnover On Earnings Persistence}

Total Assets Turnover is a ratio to determine the use of assets in generating sales (Eni, 2010). Research results by Hamidu (2013), Gunawan \& Wahyuni (2014) show that TATO significantly influences company profits. However, different results from Indriyani (2015), Anggraeni (2015) stated that TATO did not significantly influence company profits. Based on the results of the study, there were inconsistencies, so researchers wanted to reexamine the effect of Total Asset Turnover on Profit persistence. The ratio of total assets turnover is the ratio between the number of assets used in operations to the number of sales obtained in that period. This ratio is a measure of how far these assets have been used in company activities (Munawir, 2014).

The total assets turnover to find out how much the participation of assets in generating sales (Hanafi, 2016). This ratio shows the effectiveness of the company in managing these fixed assets. The ratio of total assets turnover is the ratio to measure how far these assets have been used in company activities (Munawir, 2014). This ratio is to measure the company's asset turnover and find out the number of sales obtained from each asset (Kasmir, 2015). The formula used is to divide sales by total assets. The higher the value, the better the condition of the company in maximizing its assets to generate sales. Therefore, the hypothesis is proposed as follows:

Hypothesis 3: Total Asset Turnover has a significant effect on earnings persistence

The Effect of Return On Assets on Earning Persistence
Return On Assets is rational to calculate the number of profits obtained in the previous period. So the calculation results can be used as a reference to see earnings in the next period. ROA is calculated by dividing net income by total assets (Hanafi, 2016). Return on Assets (ROA) is a ratio that shows a company's ability to make a profit from ownership of assets (Puspitawati, 2017). The results of research from Budiasih (2009), Naimah \& Utama (2006), and Indriyani (2015) show that ROA significantly influences company profits. However, different results from Ariyanti (2010) and Sofiah et al. (2017) stated that ROA did not significantly influence company profits. ROA is calculated by dividing net income by total assets. There is no standard, but a high ROA value reflects the company's return of all assets (or funding) is also significant (Hanafi, 2016). Therefore, the hypothesis is proposed as follows:

Hypothesis 4: Return on assets has a significant effect on earnings persistence

The Effect of Current Ratio, Total Debt To Total Assets, Total Asset Turnover and Return On Assets on Earning Persistence

Earnings persistence is the company's performance which is presented in the form of earnings. Persistent profit is a profit that is sustainable for a long time (Fanani, 2010). The hypothesis formulated previously shows that simultaneous CR, TDTA, TATO, and ROA have a significant effect on earnings persistence. Therefore, the hypothesis is proposed as follows:

Hypothesis 5: Simultaneously Current Ratio, Total Debt to Total Assets, Total Asset Turn Over and Return On Asset has a significant effect on earnings persistence.

\section{Research Method}

\section{Data Collection}

This type of research used in this study is quantitative research, which is the type of research that produces findings that can be generated using statistical procedures using 
regression which is a comparative approach that is to compare variables with one another with a standard. The secondary data necessary required to perform the research was gathered from the official sites of www.idx.go.id in Indonesia. Various financial statements of sixteen firms were used for data extraction. The population data used in this study are Automotive companies listed on the Indonesia Stock
Exchange in the period 2014 - 2018. As for the sample of this research obtained from the financial statements of automotive companies listed on the Indonesia Stock Exchange in the period 2014 - 2018. In determining the sample of this study using a purposive sampling method, the sample to be taken for research material has specific considerations and criteria

Table1. Sample Selection

\begin{tabular}{clc}
\hline No & \multicolumn{1}{c}{ Sample Criteria } & $\begin{array}{c}\text { Number of } \\
\text { Samples }\end{array}$ \\
\hline 1 & Automotive companies listed in Indonesia Stock Exchange & 16 \\
2 & Automotive companies that published financial statements from 2014-2018 & 8 \\
3 & Automotive companies that use Rupiah as a reference & 8 \\
4 & Number of the sample during the research period & 8 \\
\hline
\end{tabular}

\section{Variables Description}

In this study, the independent variables used include Current ratio (X1), Total Debt To Total Assets (X2), Total Asset Turnover (X3), and Return On Assets (X4), while the dependent

Table 2. Definition of operational variables variable is Profit Persistence ( Y) at automotive companies on the Indonesia Stock Exchange for the period $2014-2018$.

\begin{tabular}{|c|c|c|c|c|}
\hline No & Variable & Definition & Measurement & Source \\
\hline 1 & $\mathrm{CR}$ & $\begin{array}{l}\text { Divides total current assets } \\
\text { with current debt, meaning } \\
\text { that the value of assets is the } \\
\text { number of times current debt }\end{array}$ & $\begin{array}{c}\mathrm{CR}=\text { Total Current Assets } / \text { Total } \\
\text { Current debt }\end{array}$ & $\begin{array}{l}\text { (Munawir, } \\
\text { 2016), (Hanafi, } \\
\text { 2016), Kasmir } \\
\text { (2015) }\end{array}$ \\
\hline 2 & TDTA & $\begin{array}{l}\text { Total Debt To Total Asset } \\
\text { ratio is obtained by dividing } \\
\text { total debt by total assets }\end{array}$ & $\begin{array}{c}\text { TDTA }=\text { Total liabilities } / \text { Total } \\
\text { Assets }\end{array}$ & $\begin{array}{l}\text { (Munawir, } \\
\text { 2016), (Hanafi, } \\
\text { 2016), Kasmir } \\
\text { (2015) }\end{array}$ \\
\hline 3 & TATO & $\begin{array}{l}\text { Total Assets Turnover is a } \\
\text { ratio to determine the use of } \\
\text { assets in generating sales }\end{array}$ & TATO = Sales $/$ Total Assets & $\begin{array}{l}\text { (Munawir, } \\
\text { 2016), (Hanafi, } \\
\text { 2016), Kasmir } \\
\text { (2015) }\end{array}$ \\
\hline 4 & ROA & $\begin{array}{l}\text { ROA is calculated by } \\
\text { dividing net income by total } \\
\text { assets }\end{array}$ & ROA = Earnings after-tax / Total & $\begin{array}{l}\text { (Munawir, } \\
\text { 2016), (Hanafi, } \\
\text { 2016), Kasmir } \\
\text { (2015) }\end{array}$ \\
\hline 5 & $\begin{array}{l}\text { Earnings } \\
\text { Persistence }\end{array}$ & $\begin{array}{l}\text { Earnings persistence is the } \\
\text { desired profit later reflected } \\
\text { in the current year's earnings. }\end{array}$ & $\mathrm{Y}=\mathrm{Yt}-\mathrm{Yt}-1 / \mathrm{Yt}-1$ & $\begin{array}{l}\text { (Fanani, 2010), } \\
\text { (Barus, 2014) }\end{array}$ \\
\hline
\end{tabular}




\section{Results}

Regression Analysis

The results of the regression analysis using Statistical Programming for Social Sciences (SPSS) are presented in Table 3. Based on information depicted in Table 3 , the results of multiple linear regression are formulated as follows: $\mathrm{Y}=0.222+0.091 \mathrm{X} 1-0.961 \mathrm{X} 2+$ $0.126 \quad \mathrm{X} 3+0.134 \quad \mathrm{X} 4$.

Table 3. Regression Output

\begin{tabular}{|c|c|c|c|c|c|c|c|}
\hline \multirow{2}{*}{ Model } & \multicolumn{2}{|c|}{$\begin{array}{c}\text { Unstandardized } \\
\text { Coefficients }\end{array}$} & \multirow{2}{*}{$\begin{array}{c}\text { Standardized } \\
\text { Coefficients }\end{array}$} & \multirow{2}{*}{$\mathrm{T}$} & \multirow{2}{*}{ Sig } & \multicolumn{2}{|c|}{ Collinearity Statistics } \\
\hline & $\mathrm{B}$ & $\begin{array}{l}\text { Std. } \\
\text { Error }\end{array}$ & & & & Tolerance & VIF \\
\hline (Constant) & 0,222 & 0,306 & & 0,726 & 0,474 & & \\
\hline$C R$ & 0,091 & 0,144 & 0,121 & 0,633 & 0,532 & 0,851 & 1,176 \\
\hline TDTA & $-0,961$ & 0,505 & $-0,351$ & $-1,903$ & 0,068 & 0,923 & 1,084 \\
\hline TATO & 0,126 & 0,115 & 0,209 & 1,097 & 0,283 & 0,861 & 1,162 \\
\hline$R O A$ & 0,134 & 1,355 & 0,018 & 0,099 & 0,922 & 0,898 & 1,114 \\
\hline
\end{tabular}

a.Dependent Variable: Earnings Persistence

From the regression model as presented in Table 3, it can be explained that constant value shows that if there is no value of the independent variables namely CR, TDTA, TATO, and ROA, then the change in the value of earnings growth as seen from the value of $\mathrm{Y}$ remains at 0.222 . Regression Coefficient X1 (Current Ratio) of 0.091 means that if the Current Ratio increases by $1 \%$, the earnings persistence increases by $9.1 \%$ if other variables are constant. Regression coefficient X2 (Total Debt To Total Assets) of 0.961 means that if the Total Debt To Total Assets increases by $1 \%$, then the persistence of earnings decreases by $96.1 \%$ if other variables are constant. Regression Coefficient X3 (Total Asset Turnover) of 0.126. Meaning that if the Total Asset Turnover rises by $1 \%$, then the earnings persistence increases by $12.6 \%$ if other variables are constant. Regression Coefficient X4 (Return On Assets) of 0.134. Meaning that if the Return On Assets increases by $1 \%$, then the persistence of earnings has an increase of $13.4 \%$ if other variables are constant.

\section{Hypothesis Testing}

Based on the information in table 3, the results of the hypothesis test can be concluded that the Current Ratio has a significant effect on Earnings Persistence. Partial calculation results (t-test) was obtained a significance value of 0.532. Because the significant value of the Current Ratio is higher than 0.05 , it can be concluded that the Current Ratio has no partial effect on earnings persistence, it indicates that changes that occur in the Current Ratio will not have a significant effect on earnings persistence value. Therefore, hypothesis 1 , which states the Current Ratio has a significant effect on the persistence of the proposed earnings is rejected. The results of this study support the research of Gunawan \& Wahyuni (2014) and Sitanggang \& Vivandi, (2015), which states that the Current Ratiot has no significant effect on earnings persistence.

Total Debt To Total Assets has a Significant Effect on Earnings Persistence. Partial calculation results (t-test) was obtained a significance value of 0.068 . Because the significant value of Total Debt To Total Assets is higher than 0.05 , it can be concluded that Total Debt To Total Assets has no partial effect on earnings persistence. It indicates that changes that occur in Total Debt To Total Assets will not significantly influence the value of earnings persistence. Therefore, Hypothesis 2 which states Total Debt To Total Assets has a significant effect on the persistence of the proposed earnings, is rejected. The results of this study support the research of Gunawan \& 
Wahyuni (2014) and Sitanggang \& Vivandi, (2015) which states that Total Debt To Total Assets has no significant effect on earnings persistence.

Total Asset Turnover has a Significant Effect on Earnings Persistence. Partial calculation results (t-test) was obtained a significance value of 0.283. Because the significant value of the Total Asset Turnover is higher than 0.05 , it can be concluded that the Total Total Asset Turnover has no partial effect on earnings persistence. It indicates that changes that occur in the Total Asset Turnover will not affect the significant value of earnings persistence. Therefore, Hypothesis 3 which states the Total Asset Turnover has a significant effect on the persistence of the proposed earnings is rejected. The results of this study support research from Indriyani (2015) and Anggraeni (2015) which state that Total Asset Turnover has no significant effect on earnings persistence.
Return on Assets has a significant effect on Earnings Persistence. The partial calculation (t-test) results obtained a significance value of 0.922. Because the significant value of Return on Assets is higher than 0.05, it can be concluded that Return On Assets has no partial effect on earnings persistence. It indicates that changes that occur in Return On Assets will not have a significant effect on the value of earnings persistence. Therefore, Hypothesis 4 which states Return On Assets has a significant effect on the persistence of the proposed profits is rejected. The results of this study support research from Ariyanti (2010) and Sofiah, Mardani, \& Slamet (2017) which states that Return On Assets has no significant effect on earnings persistence.

Simultaneously Current Ratio, Total Debt to Total Assets, Total Asset Turn Over and Return On Asset Have a Significant effect on Earnings Persistence.

Table 4. F-Test Outcome

\begin{tabular}{lccccc}
\hline \multicolumn{5}{c}{ ANOVA } \\
\hline Model & Sum of Squares & df & Mean Square & F & Sig. \\
\hline Regression & 0,652 & 4 & 0,163 & 1,227 & 0,323 \\
Residual & 3,586 & 27 & 0,133 & & \\
Total & 4,237 & 31 & & & \\
\hline
\end{tabular}

With a significance level of $5 \%$, the degree of freedom (df) is $=4, \mathrm{~N}$ is 144 samples and $\mathrm{X}$ is four variables. So we get the value df2 $=140$ (obtained from the calculation of the number of $\mathrm{N}$ - number $\mathrm{x}$ ) so we get $\mathrm{F}$ table 4 : $140=2,440$. In the calculation, the calculated $F$ value is smaller than the $\mathrm{F}$ table, which is 1,277 $<2,440$. It can be concluded that simultaneously the independent variables (X) do not affect the dependent variable (Y). Meanwhile, if seen from the calculated sig value obtained a value of 0.323 . Where the sig value of 0.323 is greater than $0.05(0.323>0.05)$. It can be concluded simultaneously that the independent variable $(\mathrm{X})$ does not affect the dependent variable (Y). The results of the above study prove that the hypothesis stating that simultaneous Current Ratio, Total Debt To Total Assets, Total Asset
Turnover and Return On Assets has a significant effect on earnings persistence is rejected.

\section{Conclusion, Implication, and Limitation}

\section{Conclusion}

This study investigated the effect of CR, TDTA, TATO, and ROA on Earnings Persistence in Automotive Companies listed on the Indonesia Stock Exchange for the period 2014 - 2018 partially and simultaneously. The statistical result shows that the Current Ratio, Total Debt To Total Assets, Total Asset Turnover and Return On Assets there is no significant effect on Earnings Persistence both partially and simultaneously. It is because the statistical results show that the significant value exceeds 0.05 , It can be concluded that in this study the independent variables did not influence the 
dependent variable on automotive companies listed on the IDX

\section{Implicatication}

Based on the results of these studies, the implications can be stated theoretically and practically as follows; 1) Theoretical Implications, The selection of variables in this research is based on theory and previous research. There are research inconsistencies regarding the effect of independent variables (CR, TDTA, TATO, and ROA) on the dependent variable (Earnings Persistence). The difference is due to different research objects so that the statistical values obtained get different results. 2) Practical Implications, the result of this study is used as input for the researchers to determine the effect of independent variables on the dependent variable in adding insight into the assessment of different research objects.

\section{Limitation}

There are four variables tested, namely $\mathrm{CR}$, TDTA, TATO, and ROA, only contributed $2.8 \%$ effect on the Profit Persistence, while other variables influenced the remaining $97.2 \%$. So it is recommended for further researchers to look for other variables that are more likely to affect earnings persistence. The author suggests that the next researcher includes more variables in the profitability ratios such as Return On Investment (ROI), Net Profit Margin (NPM) or Return On Equity (ROE) because these ratios have the potential to influence Profit Persistence.

\section{References}

Anggraeni, K. (2015). Pengaruh Rasio Likuiditas, Rasio Leverage, dan Rasio Aktivitas Terhadap Pertumbuhan Laba Pada Perusahaan Otomotif di Bursa Efek Indonesia (BEI). Katalogis , 3 (9).

Anoraga, P. (2009). Manajemen Bisnis. Jakarta: Rineka Cipta.

Ariyanti, L. E. (2010). Analisis Pengaruh CAR, NIM, LDR, NPL, BOPO, ROA dan
Kualitas Aktiva Produktif Terhadap Perubahan Laba Pada Bank Umum di Indonesia. Tesis . Semarang: Program Studi Magister Akuntansi Universitas Diponegoro.

Baehaqi, M. (2016). Analisis Total Assets Turnover (TATO), Net Profit Margin (NPM), dan Return on Assets (ROA) Terhadap Pertumbuhan Laba Pada Perusahaan Otomotif di Bursa Efek Indonesia. Brancshmark, 2(1).

Barus, A. (2014). Analisis Faktor-Faktor yang Mempengaruhi Persistensi Laba Pada Perudahaan Manufaktur di Bursa Efek Indonesia. JWEM (Jurnal Wira Ekonomi Mikroskil) , 4(2), 71-80.

BEI. (2019). www.idx.co.id. Dipetik Juli 2019, dari perusahaan-tercatat/laporankeuangan-dan tahunan/: http://www.idx.co.id

Boedi, S., \& Indra, M. (2016). Analisis Rasio Keuangan Perusahaan Otomotif yang terdaftar pada Bursa Efek Indonesia. Jurnal Manajemen dan Akuntansi , 13(1).

BPS. (2019, Juni 2). www.bps.go.id. Dipetik Agustus 15, 2019, dari Ekonomi Indonesia 2018: http://www/bps.go.id

Budiasih, I. (2009). Faktor-Faktor yang Mempengaruhi Praktik Perataan Laba. Jurnal Akuntansi dan Bisnis , 4(1), 1-14.

Detik. (2018).

https://finance.detik.com/infrastruktur/d4268776/jokowi-bangun-3432-km-jalannasional-dan-941-km-jalan-tol. Dipetik 2019, dari Jokowi Bangun $3.432 \mathrm{Km}$ Jalan Nasional dan $941 \mathrm{Km}$ Jalan Tol: http://detik.com

Fanani, Z. (2010). Analisis Faktor-Faktor Penentu Persistensi Laba. Jurnal Akuntansi dan Keuangan Indonesia , 7(1), 109-123.

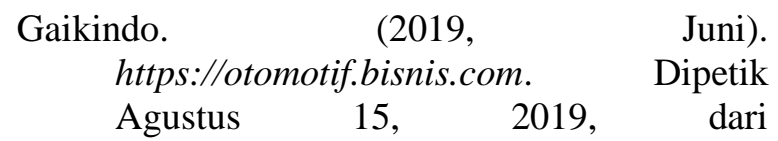


https://otomotif.bisnis.com/read/2010116/

275/879166/gaikindo-penjualan-mobil-

baru-2018-capai-115-juta:

https://otomotif.bisnis.com

Gunawan, A., \& Wahyuni, S. (2014). Pengaruh rasio keuangan terhadap pertumbuhan laba pada perusahaan perdagangan di Indonesia. Jurnal Ilmiah Manajemen dan Bisnis , 13(1).

Hamidu, N. (2013). Pengaruh kinerja keuangan terhadap pertumbuhan laba pada perbankan di BEI. Jurnal EMBA: Jurnal Riset Ekonomi, Manajemen, Bisnis dan Akuntansi , 1(3).

Hanafi, M. (2016). Analisis Laporan Keuangan. Yogyakarta: UPP STIM YKPN.

Hanifah, U., \& Khafid, M. (2016). Hanifah, U., \& Khafid, M. (2016). The Analysis of Earnings Persistence Roles in Mediating The Effect of Operating Cash Flow and Debt Level on Stock Return. Accounting Analysis Journal , 5(4), 290-298.

Hapsari, E. A. (2007). Analisis Rasio Keuangan untuk Memprediksi Pertumbuhan Laba (Studi Kasus: Perusahaan Manufaktur yang terdaftar di Bursa Efek Jakarta periode 2001 sampai dengan 2005. Doctoral dissertation, Program Pascasarjana Universitas Diponegoro . Semarang: Universitas Diponegoro.

Hapsari, E. I. (2012). Kekuatan Rasio Keuangan dalam Memprediksi Kondisi Financial Distress Perusahaan Manufaktur di BEI. Jurnal Dinamika Manajemen , 3(2).

Indriyani, I. (2015). Pengaruh Rasio Keuangan Terhadap Pertumbuhan Laba Pada Perusahaan Pertambangan yang Terdaftar di Bursa Efek Indonesia. Jurnal Manajemen Bisnis Sriwijaya , 13 (3), 343358.

Kasmir. (2015). Analisis Laporan Keuangan. Jakarta: Rajagrafindo.

Kurniasih, B., \& S.Sri. (2012). Pengaruh Ukuran Perusahaan, Profitabilitas, Leverage, dan
Kepemilikan Institusional terhadap Perataan Laba: Studi Empiris Pada Perusahaan Food and Beverages yang Terdaftar di BEI. Dinamika Akuntansi Keuangan dan Perbankan , 1(2).

Mahaputra, I. (2012). Pengaruh Rasio-Rasio Keuangan Terhadap Pertumbuhan Laba Pada Perusahaan Manufaktur Yang Terdaftar Di BEI. Jurnal Ilmiah Akuntansi dan Bisnis .

Mahardhika, P., \& Marbun, D. (2016). Pengaruh Current Ratio Dan Debt To Equity Ratio Terhadap Return On Assets. Widyakala Journal , 3, 23-28.

Munawir. (2014). Analisa Laporan Keuangan. Yogyakarta: Liberty.

Naimah, Z., \& Utama, S. (2006). Pengaruh ukuran perusahaan, pertumbuhan, dan profitabilitas perusahaan terhadap koefisien respon laba dan koefisien respon nilai buku ekuitas: Studi pada perusahaan manufaktur di Bursa Efek Jakarta. Simposium Nasional Akuntansi IX, 1(26).

Nurpitasari, N., Paramita, P., \& A.Pranaditya. (2018). Pengaruh Rasio Likuiditas, Rasio Solvabilitas Dan Rasio Activity Terhadap Kinerja Keuangan Yang Mempengaruhi Laba Perusahaan PT Dong Bang Indo Tahun 2013-2016. Journal Of Accounting , 4(4).

Pramesti, D., Wijayanti, A., \& Nurlela, S. (2016). Pengaruh Rasio Likuiditas, Leverage, Aktivitas Dan Firm Size Terhadap Profitabilitas Perusahaan Sub Sektor Otomotif Dan Komponen Di Bursa Efek Indonesia. Seminar Nasional IENACO:ISSN 2337-4349, 810-817.

Priyatno, D. (2018). SPSS Panduan Mudah Olah Data bagi Mahasiswa dan Umum. Yogyakarta: Andi Offset.

Puspitawati, A. (2017). Pengaruh Return On Asset, Current Ratio, Total Asset Turnover dan Pertumbuhan Penjualan 
terhadap Perubahab Laba Perusahaan Otomotif di Bursa Efek Indonesia.

Rizkiyah, E. (2010). Faktor-faktor yang Mempengaruhi Pertumbuhan Laba Pada Perusahaan Otomotif yang Go Publik Di Bursa Efek Indonesia. Universitas pembagunan nasional "Veteran" , Jawa Timur.

Romasari, S. (2013). Pengaruh Persistensi Laba, Struktur Modal, Ukuran Perusahaan dan Alokasi Pajak Antar Periode Terhadap Kualitas Laba (Studi Empiris pada Perusahaan Manufaktur yang Terdaftar di BEI). Jurnal Akuntansi , 1(2).

SafaeianRezi, M., \& Sadeghi, M. (2009). Evaluation of investment decisions as it relates to the sustainability of profits companies listed in Tehran Stock Exchange. First Year, Issue 3, 69-87 7.

Safitri, Y. (2019, Januari 31). Analisis Pengaruh Rasio Keuangan (Likuiditas, Solvabilitas, Aktivitas, dan Profitabilitas) Terhadap Pertumbuhan Laba pada Perusahaan Manufaktur yang Terdaftar di Bursa Efek Indonesia tahun 2011-2016. Diambil kembali dari http://repository.usu.ac.id: http://repository.usu.ac.id

Sapariyah, R. (2010). Pengaruh Rasio Capital, Assets, Earning dan Liquidity terhadap Pertumbuhan Laba pada Perbankan Di Indonesia (Study Empiris Pada Perbankan Di Indonesia). Pro Bank, 1(3).

Sholihah, M. A. (2012). Analisis Pengaruh Rasio Keuangan Terhadap Laba Perusahaan Manufaktur Di BEI. Doctoral dissertation, Universitas Muhammadiyah Surakarta .

Sitanggang, R., \& Vivandi, Y. (2015). Rasio Keuangan terhadap laba pada perusahaan. Jurnal Manajemen Bisnis Transportasi dan Logistik , 1(2), 273-292.

Sofiah, L., Mardani, R., \& Slamet, A. (2017). Pengaruh Laba, Arus Kas dan ROA Dalam Memprediksi Laba yang akan datang (Studi Empiris Pada Perusahaan Industri Barang Komsumsi Go Public di BEI Periode 2014-2015). Jurnal Ilmiah Riset Manajemen , 6(2).

Sosiawan, S. (2012). Pengaruh kompensasi, leverage, ukuran perusahaan, earnings power terhadap manajemen laba. Jurnal Riset Akuntansi dan Keuangan , 8(1), 7989.

Sugiyono. (2017). Metode Penelitian Kuantitatif Kualitatid dan $R \& D$. Bandung: Alfabeta.

Sujarweni. (2018). Metodologi Penelitian. Bantul: Pustaka Baru Press.

Susilawati, S., \& Iskandar, F. (2017). Pengaruh Current Ratio, Quick Ratio Dan TATO Terhadap Laba Bersih PT. Indosat Tbk Periode 2005-2013. Eksis: Jurnal Ilmiah Ekonomi dan Bisnis , 6(1), 30-46.

Suwito, E., \& Herawaty, A. (2005). Analisis Pengaruh Karakteristik Perusahaan Terhadap Tindakan Perataan Laba Yang Dilakukan Oleh Perusahaan Yang Terdaftar di Bursa Efek Jakarta. Seminar Nasional Akuntansi VIII , 136-146.

Taruh, V. (2012). Analisis Rasio Keuangan Dalam Mempresiksi Pertumbuhan Laba Pada Perusahaan Manufaktur di BEI. Jurnal Pelangi Ilmu, 5(01).

Tempo. (2019). Penjualan Sepeda Motor. Dipetik Juli 2019, 18, dari https://www.tempo.co/tag/penjualansepeda-motor: https://www.tempo.co/tag/penjualansepeda-motor

Yulia, M. (2013). Pengaruh Ukuran Perusahaan, Profitabilitas, Financial Leverage, Dan Nilai Saham Terhadap Perataan Laba (Income Smoothing) Pada Perusahaan Manufaktur, Keuangan Dan Pertambangan Yang Terdaftar Di Bursa Efek Indonesia (BEI). Jurnal Akuntansi, 1(2).

Yusra, I. (2016). Kemampuan Rasio Likuiditas Dan Solvabilitas Dalam Memprediksi 
Laba Perusahaan Perusahaan: Studi Empiris Pada Perusahaan Telekomunikasi Yang Terdaftar Di Bursa Efek Indonesia. Jurnal Benefita: Ekonomi Pembangunan, Manajemen Bisnis dan Akuntansi , 1(1), 15-23. 